PAWEE T. DOBROWOLSKI

Collegium Civitas, Warszawa

\title{
POWOZEM NA SZAFOT. TEATRY SKRUCHY W OSIEMNASTOWIECZNYM LONDYNIE
}

Pamięci Bronisława Geremka

W środę, 14 stycznia 1767 r. londyński przedsiębiorca Samuel Orton udał się w swoją ostatnią podróż. Trwała kilka godzin i wiodła z celi skazańców więzienia w Newgate na Tyburn, zwyczajowe miejsce straceń stołecznych przestępców. Nie podróżował sam. Na dwóch wózkach, które podążały za nim, wieziono dwudziestosześcioletniego Thomasa Thornhilla, zwanego kapitanem ze względu na wcześniejszą służbę wojskową, oraz równie młodych marynarzy, Walkera i Johnstona ${ }^{1}$. Orton przewodził tej kawalkadzie nie tylko z racji wieku (miał 43 lata) i swojej pozycji społecznej, którą górował nad pozostałymi skazańcami. Na śmierć udawał się innym środkiem lokomocji, „pogrzebowym powozem” („mourning coach”), co z należytą uwagą podkreślały relacje prasowe. Jakie znaczenie miała ta różnica, zważywszy, że u kresu podróży wszystkich czekała taka sama kara: publicznie zadana śmierć przez powieszenie? Czy nie należy w tym odczytywać śladów „klasowego” zróżnicowania angielskiego społeczeństwa, dobrze już widocznych w połowie XVIII w. i demonstrowanych nawet w tak szczególnych okolicznościach? Taka interpretacja nawiązywałaby do znanych tez historyków związanych ze „szkołą z Warwick”, która angielski system prawa karnego odczytywała przez pryzmat paradygmatu dominacji „właścicieli" prawa nad plebejuszami, widząc w tych drugich upośledzony przedmiot jego funkcjonowania ${ }^{2}$. Lektura relacji o tej egzekucji ukazuje

1 „London Magazine” 36, 1767, s. 41. Konkurencyjny „Gentleman's Magazine” (39, 1767, s. 20, 44) opublikował znacznie krótszą relację (wszystkie tłumaczenia w tekście moje - P.D.).

${ }^{2}$ Klasyczna ekspozycja tezy o ideologicznej funkcji osiemnastowiecznego angielskiego prawa karnego w: D. Hay, Property, Authority and the Criminal Law, w: Albion's 
odmienności, które zdają się wskazywać jeśli nie na „klasową”, to na dostrzeganą przez wszystkich obyczajową różnicę, na inne traktowanie. Wszyscy czterej skazańcy wisieli „tyle co trzeba” (,the usual time”), jednak potem ich ciała potraktowano inaczej: Ortona i Thornhilla zabrano w karawanach (,in hearses”), Johnstona złożono w trumnie, a ciało drugiego z ludzi morza zabrali marynarze, którzy w tym celu przybyli na egzekucje. Rozróżnienia te oraz ich prawne, obyczajowe i kulturowe implikacje stanowić będą przedmiot poniższych uwag.

Badania nad wczesnonowożytnymi „teatrami śmierci”, publicznymi egzekucjami, ich osadzoną w zapisach prawa regulacją oraz kulturową i społeczną funkcją posiadają już wieloletnią metrykę i zaowocowały znacznymi osiągnięciami. Stały się osobnym tematem analiz prowadzonych na pograniczu historii przestępczości, wkraczając w domenę badań nad ewolucją prawa karnego, ugruntowanego społecznego zwyczaju, plebejskiej obyczajowości, a także historii emocji i psychologii. Historyków nie interesują już tylko same procesy tworzenia kategorii prawa karnego, ich praktycznego zastosowania oraz statystyki wczesnonowożytnej przestępczości. Szukamy z jednej strony - jak Pieter Spierenburg - wyjaśnienia takiego społecznego zakorzenienia indywidualnych tragedii (w przypadku studium do którego się odwołuję - miłości, jako motywu zbrodni), które rzuca światło na różne kultury międzyludzkich relacji, ukazania „głębokiego kontekstu” zbiorowych obsesji prowadzących - jak opisywał to w przypadku kolonialnego Nowego Jorku Mark Fearnow - do „histerii zabijania”, wieszania wszystkich, którzy zdawali się zagrażać stabilności „małomiasteczkowej” wspólnoty (Nowy Jork liczył w pierwszej połowie XVIII w. do 10 tys. mieszkańców), albo też jak pokazywała Florike Egmond na przykładzie Niderlandów - odtworzenia sposobu koegzystencji i działania drugiego, przestępczego i dobrze zorganizowanego, alternatywnego społeczeństwa ${ }^{3}$.

Przypadek Anglii eksploatowany bywa często i z powodzeniem zarówno z racji bogactwa i uporządkowania podstawy źródłowej,jak i konstatacji powtarzanej przez wielu historyków o wyjątkowo surowym egzekwowaniu przepisów prawa karnego ${ }^{4}$. Warto przypomnieć, że twórcą

Fatal Tree: Crime and Society in Eighteenth-Century England, red. D. Hay et al., London 1975, s. 17-63. Idąc tym tropem, analizę panoramy „plebejskich ofiar” systemu prawa karnego przeprowadził Peter Linebaugh, The London Hanged: Crime and Civil Society in the Eighteenth Century, London 1991.

${ }^{3}$ P. Spierenburg, Written in Blood: Fatal Attraction in Enlightenment Amsterdam, Columbus, Ohio 2004; F. Egmond, Underworlds. Organized Crime in the Netherlands,1650-1800, Cambridge 1993; M. Fearnow, Theatre for an Angry God. Public Burnings and Hangings in Colonial New York, 1741, „The Drama Review” 40, 1996, 2, s. 15-36.

${ }^{4}$ Rejestry tysięcy spraw kryminalnych sądzonych przez londyński trybunał karny 
nowoczesnych badań nad historią angielskiego prawa karnego był Polak (sir) Leon Radzinowicz, który przybył na wyspy w 1938 r. z rekomendacją Ministerstwa Sprawiedliwości RP i przez następne dziesięciolecia położył podwaliny pod osiągnięcia współczesnej anglosaskiej historiografii tej dyscypliny ${ }^{5}$. Już pierwsze studia Radzinowicza koncentrowały się na angielskim Bloody code, sięgającym elżbietańskich korzeni zbiorze statutów, które kwalifikowały nawet drobne wykroczenia (kategorii było razem blisko 200), przede wszystkim przeciw mieniu, jako przestępstwa zagrożone karą główną. Wiek XVIII uchodził za apogeum tak rozumianej i wcielanej w życie penalizacji.

Pokłosiem badań Radzinowicza była wszczęta w latach siedemdziesiątych XX w. przez Douglasa Haya i Johna Langbeina debata nad społecznymi uwarunkowaniami funkcjonowania prawa. Zaowocowała - dzięki badaniom Petera Linebaugh, Johna Beattie, Simona Devereaux i innych ustaleniami szczegółowymi, które potwierdzają, że od początku XVIII w., a na pewno już od połowy tego stulecia trwała w Anglii żywa polemika dotycząca „strategii karania”. Poszukiwanie równowagi między karaniem na gardle - uwagi Michela Foucault ${ }^{6}$ pozostają zawsze istotne dla historyków przestępczości - a deportacją oraz narzędziami łagodniejszymi niż kara główna spowodowało powolne zakwestionowanie dydaktycznej skuteczności wieszania. Przyczyniła się do tego zarówno znajomość traktatu Cesare Beccarii Dei delitti e delle penne (1764), który już w 1767 r. został przełożony na angielski, obserwacje własne dokonywane przez angielskich jurystów z sędzią Williamem Blackstonem na czele oraz generalne zakwestionowanie „wydajności” sposobu wykrywania przestępstw i skuteczności szafowania wyrokami śmierci za przestępstwa pospolite ${ }^{7}$. Już

w budynkach przy ulicy old Bailey są dostępne on-line (http://www.oldbaileyonline. org) w ramach projektu, którego koordynatorem jest Tim Hitchcock (University of Hertfordshire).

${ }^{5}$ L. Radzinowicz, A History of English Criminal Law and its Administration from 1750, t. 1: The Movement for Reform 1750-1833, New York 1948. Przegląd ewolucji anglosaskiej historiografii ostatniego stulecia w: B. P. Smith, English Criminal Justice Administration, 1650-1850: A Historiographic Essay, „Law and History Review” 25, 2007, 3, s. 593-634.

${ }^{6}$ Korzystam z wyd. ang. M. Foucault, Discipline and Punish, London 1977 (oryg. franc. 1975).

${ }^{7}$ Pierwotne ramy dyskusji wyznaczyli D. Hay, op. cit., s. 17-63 i J.H. Langbein, Albion's Fatal Flaws, „Past \& Present” 1983, 98, s. 96-120. Przegląd tej fazy badań w: J. Innes, J. Styles, The Crime Wave: Recent Writing on Crime and Criminal Justice in Eighteenth-Century England, „Journal of British Studies” 25, 1986, 4, s. 380-435. Zob. J. M. Beattie, Crime and the Courts in England, 1660-1800, Princeton, N. J. 1986; idem, Policing and Punishment in London, 1660-1750: Urban Crime and the Limits of Terror, Oxford 2001; S. Devereaux, The Making of the Penitentiary Act, 1775-1779, „The Historical Journal” 42, 1999, 2, s. 405-433; A.J. Draper, Cesare Beccaria's Influence on English Discussion of Punishment, 1764-1789, „History of European Ideas" 26, 2000, 3/4, s. 177-199. 
w 1725 r. naturalizowany w Anglii holenderski lekarz Bernard Mandeville $\mathrm{w}$ traktacie An Inquiry into the Causes of the Frequent Executions at Tyburn gwałtownie krytykował „teatr” wieszania i uważał, że publiczne egzekucje stanowią zachętę do ekscesów, zamiast pełnić funkcję narzędzia odstraszającego przestępców. Bardziej wnikliwą analizę „strategii karania” przeprowadził Henry Fielding, pisarz i urzędnik sądowy, którego rozprawa An Enquiry into the Causes of the Late Increase of Robbers, napisana w 1751 r. pod wpływem fali przemocy, napadów i włamań, która ogarnęła Londyn, proponowała zamykanie skazańców w więzieniach i „prywatyzację" wykonywania kary śmierci. Fielding zwracał przede wszystkim uwagę na niedostateczny system wykrywania przestępstw, na sprowadzanie pokrzywdzonych do roli niemych świadków i na ogólną niemoc systemu wymierzania sprawiedliwości w wielkiej metropolii, której ulice roiły się nie tylko od ludzi łatwo przechodzących od obraźliwych słów do gwałtownych czynów, ale także rzeszy znacznie bardziej groźnych złoczyńców i przestępców ${ }^{8}$. Statystyki sądów konsystorskich zajmujących się najbardziej błahymi - sąsiedzkimi - wykroczeniami wskazują, że w okresie 1730-1760 r. aż 53\% spraw dotyczyło gróźb użycia fizycznej siły ${ }^{9}$. Chociaż liczba wykroczeń drobniejszych, niezagrożonych karą główną także wy-

${ }^{8}$ Przełomowe znaczenie „półprywatnego” aresztu śledczego braci Fielding przy Bow Street dla ewolucji procedur sądowych przeanalizował J. M. Beattie, Sir John Fielding and Public Justice: The Bow Street Magistrates' Court, 1754-1780, „Law and History Review" 25, 2007, 1, s. 61-100.

${ }^{9}$ Za typową uznać można następującą relację prasową: „Among the many desperate and cruel robberies that were committed about this time three persons returning to Town from Islington about 7 in the evening on Sunday, Feb. 26 [1749 r. - P.D.] were attak'd in Frog-Fields near that place by 3 fellows, who came from behind the barn, and Mr. John Scot foreman to a taylor in Old-Broad street, making some resistance, one of the rogues cut him down the back part of the head with a hanger [tasak P.D.]. They than made their escapes, leaving his two companions whom they had robb'd to take care of him. He was carried to the Red-Lion at Islington, where he languished for 2 or 3 days, and than expired”, zob. „London Magazine” 18, 1749, s. 141. Na podstawie żartów i anegdot Simon Dickie (Hilarity and Pitlessness in the Mid-Eighteenth Century: English Jestbook Humor, „Eightetenth-Century Studies” 37, 2003, 1, s. 1-22) zakreślał kulturowe pole obszarów plebejskiej (językowej) agresji. Por. R. B. Shoemaker, The Decline of Public Insult in London 1660-1800, „Past \& Present” 2000, 169, s. 117; P. Smith, Executing Executions: Aesthetics, Identity, and the Problematic Narratives of Capital Punishment Ritual, „Theory and Society” 25, 1996, 2, s. 248 nn.; S. Devereaux, Recasting the Theatre of Execution: the Abolition of the Tyburn Ritual, „Past \& Present” 2009, 202, s. 146 n.; T. W. Laqueur, Crowds, Carnival and the State in English Executions, 1604-1868, w: The First Modern Society: Essays in English History in Honour of Lawrence Stone, red. A.L. Beier, D. Cannadine, J. M. Rosenheim, Cambridge 1989, s. 305-355. Paryskie przestrzenie miejskiej przestępczości omawiali Arlette Farge i Andre Zysberg, Les Theâtres de la violence à Paris au XVIII ${ }^{e}$ siècle, „Annales. Histoire, Sciences Sociales” 34, 1979, 5 , s. 984-1015. 
kazuje tendencję wzrostową, to jednak wyrok skazujący na śmierć przez powieszenie pozostawał przez cały XVIII w. podstawowym narzędziem odstraszenia i - z oczywistych powodów - przyciągał uwagę prawników, komentatorów oraz autorów źródeł narracyjnych. Można argumentować, że mieli po temu powody: kolejne „fale przestępczości” powodowały, iż spektakl wieszania był londyńczykom dobrze znany. W latach 1770-1775 wieszano (średnio) 37 skazańców rocznie, po 1780 r. liczba wykonanych egzekucji wzrosła najpierw o 30 , potem o $70 \%{ }^{10}$. Nie powinniśmy jednak ulegać stereotypowi wszechobecnej i powszechnie stosowanej najwyższej kary. Analizy orzecznictwa wskazują, że sądy wydawały wyroki śmierci $z$ rozwagą. Nawet w przypadku przestępstw nią zagrożonych (morderstwa, napady i włamania) zdarzało się, że wyrok zamieniano na lżejszy. Wedle współczesnych danych, zebranych przez burmistrza Londynu Theodore'a Janssena, w latach 1749-1771 na śmierć skazano 1121 przebywających w Newgate przestępców: aż 443 z nich uniknęło kary (401 zamieniono wyrok śmierci na deportacje). Wśród przestępców, których czyny „ustawowo" wiodły na szafot, procent tych, którym udało się przeżyć, był znaczny: na 81 schwytanych i skazanych morderców powieszono 72, na 362 bandytów „drogowych” wyrok wykonano na 251, na 208 włamywaczy powieszono 118, na 80 kieszonkowców tylko 27. Jak ustalił Langbein na przykładzie losów 203 oskarżonych, którzy w okresie 1754-1756 r. stawali przed londyńskim sądem w Old Bailey, aż 83 zostało uniewinnionych decyzją ławy przysięgłych. Londyński sąd karny odbywał rocznie osiem sesji, podczas których „oczyszczał więzienie”: wymierzał wyroki wszystkim przetrzymywanym w Newgate podejrzanym, których zatrzymano w Londynie oraz w przyległym hrabstwie Middlesex. Procedura trwała szybko, pojedyncze sprawy zwykle nie zajmowały sędziom więcej niż godzinę. Po przyjęciu statutu zw. Murder Act w 1752 r. egzekucje wykonywano najpóźniej w dwa dni po zapadnięciu wyroku. Przebieg procesu oraz sentencję publikowano (tzw. sessions paper) i stawała się ona materiałem dostępnym dla wszystkich zainteresowanych, przede wszystkim dla gazet. Służyła także jako podstawa dokumentacji w petycjach o ułaskawienie ${ }^{11}$.

W Londynie egzekucje wykonywano do 1783 r. na rozdrożu Tyburn (obecnie okolice Marble Arch), leżącym poza murami miasta, w parafii

10 S. Devereaux, Imposing the Royal Pardon: Execution, Transportation, and Convict Resistance in London, 1789, „Law and History Review” 25, 2007, 1, s. 120.

${ }^{11}$ Idem, The City and the Sessions Paper: „Public Justice” in London, 1770-1800, , Journal of British Studies" 35, 1996, 4, s. 466-503; idem, Imposing the Royal Pardon, s. 101-138; J.H. Langbein, op. cit., s. 106, 110. Tendencję wzrostu liczby przestępstw pospolitych analizował Peter King, Punishing Assault: The Transformation of Attitudes in the English Courts, „The Journal of Interdisciplinary History” 27, 1996, 1, s. 43-74. 
pw. Najświętszej Marii Panny „przy potoku” (dziś Marylebone), gdzie w 1571 r. wzniesiono szubienice - przezywaną ,stołkiem na trzech nogach”, na której można było „zbiorowo” wieszać równocześnie po kilkunastu skazańców. W 1759 r. pierwotne „drzewo wisielców” zastąpiono nowym urządzeniem, przenośną szubienicą. W XVIII w. miasto wchłonęło ten teren i szubienica - oraz trybuny dla widzów spektaklu - znalazły się w obszarze zabudowanym, w okolicach ulicy Oxford, gdzie mieściły się domy mieszkalne i warsztaty. Po dwóch stuleciach regularnie wykonywanych egzekucji najlepiej rozpoznany londyński „teatr śmierci”by użyć terminu zapożyczonego od Andrei McKenzie w odniesieniu do spektakli osiemnastowiecznego wieszania - posiadał już dobrze ugruntowane miejsce w miejskiej wyobraźni i przestrzeni. James A. Sharpe, którego analiza siedemnastowiecznego umiejscowienia publicznej londyńskiej egzekucji nadal zachowuje podstawowe znaczenie, zwrócił uwagę na popularność tanich broszur (chapbooks), w których opisywano wzory „dobrej śmierci” skazańców i kładziono nacisk na dydaktyzm kary. Sharpe podkreślał religijny i „państwowy” konformizm, jaki w ostatnich chwilach życia wymuszano na skazańcach, od których oczekiwano wygłoszenia aktu publicznej skruchy oraz wskazówek dla zebranych widzów, aby nie ważyli się kroczyć ich grzeszną drogą ${ }^{12}$. Sugerował on także, że na początku XVIII w., uświęcona tradycją obecność duchownych w czasie egzekucji nie skutkowała już oczekiwaniem wygłoszenia przez skazańca budującej (dla słuchaczy) mowy, co wiązał z procesem zepchnięcia wymiaru eschatologicznego śmierci na drugie miejsce i zastąpienia go świeckim priorytetem dopełnienia sądowej procedury. Ponadto Sharpe zwracał uwagę na trwałość wczesnonowożytnej debaty wokół „odstraszająco-edukacyjnych” wartości kary śmierci, wskazywał przejawy jej spowszednienia - przypominając ludowe powiedzenie odnotowane w 1725 r., mówiące, że „powieszenie to nic takiego, tylko kark boli

${ }^{12}$ J. A. Sharpe, „Last Dying Speeches”: Religion, Ideology and Public Execution in Seventeenth-Century England, „Past \& Present” 1985, 107, s. 144-167; S. Wilf, Imagining Justice: Aesthetics and Public Executions in Late Eighteenth-Century England, „Yale Journal of Law and the Humanities” 5, 1993, s. 51-78; A. McKenzie, Martyrs of Low Life? Dying „Game” in Augustan England, „Journal of British Studies” 42, 2003, 2, s. 167-205, oraz, eadem, Tyburn's Martyrs: Execution in England, 1675-1775, London 2007; P. Linebaugh, The Ordinary of Newgate and His Account, w: Crime in England, 1550-1800, red. J. S. Cockburn, Princeton, N.J. 1977, s. 246-268; P. Spierenburg, The Spectacle of Suffering: Executions and the Evolution of Repression. From a Preindustrial Metropolis to the European Experiences, Cambridge 1984; F. E. Dolan, „Gentlemen, I have one thing more to say”: Women on Scaffolds in England, 1563-1680, „Modern Philology” 92, 1994, 2, s. 157-178; L. Masur, Rites of Execution, Oxford 1989; S. Devereaux, Recasting, s. 127-174. 
i portki ma się mokre”, ale zaznaczał także, iż tradycja „przemówień spod szafotu" wykazywała własną dynamikę i żywotnośćc ${ }^{13}$.

Poniżej będę korzystać z kilku prasowych relacji o egzekucjach na Tyburn zamieszczonych w londyńskich miesięcznikach - mediach, które w ślad za codziennymi gazetami zastąpiły w XVIII w. wcześniejsze chapbooks i w sposób przedtem nieznany (ilościowy i jakościowy) kumulowały, relacjonowały i porządkowały informację o wielu aspektach miejskiej codzienności, poświęcając niemało miejsca przestępcom, ich procesom i egzekucjom. Gazety korzystały z własnych „reporterskich” doniesień oraz z publikowanych i łatwo dostępnych session papers, wydawanych (na koszt miasta publikowano w drugiej połowie XVIII w. 320 egzemplarzy) po zakończeniu każdej z ośmiu miesięcznych sesji stołecznego trybunału, dostarczając bogactwa szczegółów każdej z orzekanych spraw ${ }^{14}$. Postaram się zwrócić uwagę na odmienności i powstające różnice w modelach „teatralizacji publicznego umierania”, które świadczyły, że w stołecznej przestrzeni Londynu w XVIII w. spektakl śmierci z wolna poddawał się zmianom, które - szybciej niż na Tyburn - zachodziły w społecznej tkance miasta.

Zwyczaj „przemówień z szafotu” utrzymywał się nadal w XVIII w., chociaż londyńska prasa - przede wszystkim z powodu natłoku informacji i ograniczonego miejsca na swoich łamach - nie relacjonowała ich zwykle in extenso. Były jednak dostępne jako element sprawozdań procesowych, których dydaktyczną rolę uznawał w 1734 r. literat Samuel Richardson, pisząc „niech sprawozdania [,,session-paper”] i mowy umierających [,dying speeches"] nieszczęśliwych zbrodniarzy [--] posłużą nierozważnej młodzieży [- ] jak w naturalny sposób, krok po kroku, przekleństwa, bluźnierstwa, prostactwo, pijaństwo, dziwkarstwo [„,whoredom”], kradzież, rabunek, mord i stryczek idą jedno po drugim"15. Publiczny pokaz skruchy

13 "there is nothing in being hang'd, but a wry neck, and a wet pair of breeches", J. A. Sharpe, op. cit., s. 165-167. Etyczny i dydaktyczny przekaz osiemnastowiecznych „kazań sądowych”, które zwyczajowo wygłaszano na początku wyjazdowej (poza Londyn) sesji sądu (tzw. assizes), analizował Randall McGowen („He Beareth Not the Sword in Vain”: Religion and the Criminal Law in Eighteenth-Century England, ,Eighteenth-Century Studies" 21, 1987-1988, 2, s. 192-211), zwracając uwagę na nacisk duchownych na egzekwowanie surowych wyroków.

${ }^{14} \mathrm{O}$ znaczeniu prasy w podejmowaniu tematyki kryminalnej zob. J. Black, The English Press in the Eighteenth Century, London 1987, s. 99-108; J. Oldham, Law Reporting in the London Newspapers, 1756-1786, ,,The American Journal of Legal History” 31, 1987, 3, s. 177-206; J. Styles, Sir John Fielding and the Problem of Criminal Investigation in Eighteenth-Century England, „Transactions of the Royal Historical Society”, 5 seria, 33, 1983, s. 135 nn.; J. M. Beattie, Sir John Fielding, s. 69 n., 85 n.

${ }^{15}$ Cyt za: S. Devereaux, The City, s. 496. Por. I. Bell, Literature and Crime in Augustan England, London-New York 1994, s. 72-74. 
pozostawał trwałym składnikiem pejzażu podlondyńskiego szafotu, chociaż prasowy „nośnik”, dzięki któremu szerzono dydaktyczny przekaz, oraz sposób opowiadania o tym londyńskiemu czytelnikowi ulegały zmianie spowodowanej zalewem różnych, nie tylko kryminalnych wiadomości. Gazety były w XVIII w. podstawowym środkiem informowania o wymierzanych karach, równolegle funkcjonowały jednak inne media: na jednej z rycin Williama Hogartha z 1747 r. zatytułowanej The Idle 'Prentice Executed at Tyburn (Egzekucja leniwego czeladnika) artysta umieścił wózek z trumną i postać duchownego, natomiast u podnóża szubienicy przedstawił siedzącą kobietę, która trzymając na jednym ręku dziecko, drugą sprzedaje (już wcześniej wydrukowaną) ,ostatnią mowę" skazańca ${ }^{16} . Z$ opisu egzekucji, która odbyła się 25 lutego 1754 r. w Ivelchester, czytelnik dowiadywał się, że „niesławny John Poulter (alias Baxter) który uciekł z więzienia i został schwytany [--] zachowywał się bardzo pokornie i przyzwoicie. Kiedy dotarł pod szubienicę, trzy razy wstawał na wózku i głośno powiedział, że nie ma żadnych podstaw stwierdzenie, iż strażnik więzienny pomógł mu w ucieczce. Potem zwrócił się do ludzi i prosił, by zważyli na jego smutny koniec i unikali złego towarzystwa. Przyznał, że zasłużył na śmierć, ale większość jego kompanów jeszcze bardziej”. Streszczenia opisów egzekucji - oraz procedur sądowych - dokonywane przez gazety oddawały zasadniczy zrąb oficjalnych sprawozdań i przekazywały skróconą wersję ostatnich słów wypowiadanych przez skazańców. W przypadku Poultera można się oczywiście zastanawiać, które fragmenty wypowiedzi zostały wcześniej „zredagowane” lub nawet uzgodnione ze skazanym. Z prasowej relacji można wnosić, że załatwiał on kilka spraw równocześnie: wygłosił standardową formułę skruchy, zdejmował winę z (zagrożonego stryczkiem) strażnika więziennego i wskazywał na (jeszcze nieschwytanych) wspólników, trwałe źródło zagrożenia dla zgromadzonych ${ }^{17}$. Trafiają się także sprawozdania prasowe, które wydają się bladym i krzywym odbi-

${ }^{16}$ Utrzymywał się także popyt na „szubieniczną” literaturę: w 1768 r. wydano w czterech tomach książkę pod znamiennym tytułem The Tyburn Chronicle; or Villainy Display'd in All Its Branches, która „w celu wsparcia cnoty i wiary” relacjonowała życiorysy powieszonych, zob. S. Devereaux, The City, s. 497. Ten typ literatury, tworzony m.in. przez więziennego kapelana, zanika po 1770 r. Por. A. McKenzie, Martyrs, s. 170 nn.; zob. B. Jaffe, William Hogarth and Eighteenth Century English Law Relating to Capital Punishment, „Law and Literature” 15, 2003, 2, s. 268 oraz il. 1. Por. bardziej wstrzemięźliwą ocenę znaczenia tej ryciny w: S. Devereaux, Recasting, s. 142.

17 ,the noted John Poulter, alias Baxter, who had made his escape out of gaol and was soon retaken,was executed at Ilvechester, behaving very penitently, and with decent resolution. As soon as he arrived at the gallows he stood up in the cart three times, declaring aloud, that the report of the gaoler's having contrived to let him escape was without any foundation. He than addressed himself to the people, desiring them to take warning by his unhappy end, and avoid bad company; acknowledging 
ciem wcześniejszego (chciałoby się powiedzieć „barokowego”) motywu „chwalebnego nawrócenia” grzesznika w obliczu śmierci. Szewc John Williamson, lat 45 , skazany za zamorzenie żony głodem został przywieziony na ulicę Chiswell na Moorfields. Wybrano inne niż zwyczajowy Tyburn miejsce egzekucji, ponieważ dydaktycznym celem było powieszenie go w dzielnicy, gdzie mieszkał i był znany. Towarzyszyło mu dwóch duchownych anglikańskich i „nauczyciel metodysta”, który modlił się za niego „pełną godzinę”. „Duchowni z wielkim trudem przymuszali go do wyznania zbrodni, w końcu - tuż przed odjazdem wózka - jeden z nich poinformował ludzi, że wyznał morderstwo i co więcej, powiedział, że jego niechlujne [,disorderly"] życie doprowadziło go do takiego nieszczęścia oraz że miał nadzieję, iż ludzie pomodlą się za jego duszę". Gazeta donosiła - nie podając niestety powodu - że egzekucji przypatrywało się 10000 osób, „w tym bardzo wiele kobiet”18.

Angielskie dokumenty sądowe oraz ich publiczny obieg generowany przez drukowane broszury streszczające poszczególne sprawy i prasowe relacje dotyczące wyników sesji trybunału Old Bailey - podstawowej londyńskiej instytucji zajmującej się ferowaniem wyroków za przestępstwa kryminalne - są materiałem unikatowym, który przynosi idące w tysiące relacje o tym, kto, za co i na jaką karę został skazany. Historycy badający angielski (brytyjski) wymiar sprawiedliwości oraz jego społeczne i kulturowe odniesienia obficie czerpali z tego zbioru, nie cofając się - mimo znanych już ograniczeń metodologicznych ciążących na takich materiałach - przed próbami ujęć statystycznych. Także lektura setek pojedynczych, krótkich prasowych zapisów o popełnionych występkach ukazuje

that he deserved to suffer death, but that most of his accomplices did more so”, „London Magazine" 23, 1754, s. 138.

18 „it was with much difficulty that the clergymen could prevail upon him to acknowledge his crime, but at last, just before the cart drew off one of the clergymen informed the people that he had confessed to murder; and further that his disorderly life had been a principal means of bringing him into that unfortunate situation, and hoped the people would pray for his soul”, „London Magazine” 36, 1767, s. 41. Konkurencyjny miesięcznik „Gentleman's Magazine” wykorzystał akta sądowe dokładniej i informował, że szewc popełnił morderstwo z premedytacją, ponieważ żona „biedna istota była niespełna rozumu [„,kind of idiot”], która otrzymała pewną kwotę pieniędzy na utrzymanie, a Williamson, aby zagarnąć pieniądze znalazł sposób, aby ją poślubić” (,the poor creature was a kind of idiot who having a sum of money left for her maintenance Williamson to possess himself of the money found means to marry her"). Następował potem opis dręczenia ofiary oraz uwaga, że zgromadzony tłum złożony z osób, które szewca znały, i z sąsiadów - chciał go rozszarpać na sztuki, wiec skazaniec sam prosił kata o szybkie wykonanie wyroku. Zob. „Gentleman's Magazine” 39, 1767, s. 44. Przestępstwa należące do kategorii „domowego okrucieństwa” omawia Margaret Hunt, Wife-Beating, Domesticity and Woman's Independence in Eighteenth Century London, „Gender and History” 4, 1992, s. 10-35. 
niezwykłą panoramę miejskiej przestępczości w największej metropolii osiemnastowiecznej Europy. W styczniu 1751 r. wyroki śmierci zasądzono m.in. zawodowemu bokserowi („stage-boxer”) Jamesowi Fieldowi, który poza wykonywaniem swego pięściarskiego fachu obrabował przechodnia z okularów, pudełka na tytoń i 13 szylingów, Williamowi Vincentowi, który ukradł komuś srebrne sprzączki do spodni, oraz Richardowi Parsonsowi, recydywiście, skazanemu na deportację, który jednak wrócił do Anglii, nie licząc się z tym, że kolejna kolizja z prawem zaprowadzi go na szubienicę. Trzynaście osób, które w tej sesji sąd skazał na śmierć, parało się przeważnie ulicznymi napadami lub włamaniami i kradzieżą: zastawy stołowej, zegarków, pieniędzy, kapeluszy, peruk. Nie tracąc z pola widzenia wyroków śmierci - i egzekucji - należy jednak podkreślić, że ewolucja wymiaru brytyjskiej sprawiedliwości wykazuje w XVIII w. trwałą tendencję do zmniejszania liczby takich wyroków na rzecz deportacji, uznawanej za sposób zastępczy wymierzania kar surowych oraz ich zamieniania na kary lżejsze. W cytowanej styczniowej sesji sądu Old Bailey poza 13 wyrokami śmierci zasądzono także 35 deportacji do kolonii oraz dwa przypadki naznaczenia rozpalonym żelazem. Ta ostatnia kategoria, obok wydawanego wyroku kary pręgierza, należała do typowych sposobów naznaczania „karami publicznego wstydu”, form nakładania infamii, których zakorzenioną w tradycji społeczną obecność i żywotność znakomicie ukazała Natalie Zemon Davis ${ }^{19}$. Deportacja do Ameryki Północnej - na 7, 14 lat lub dożywotnio - uznawana była za karę społecznie korzystną i wymierzaną zastępczo zamiast wyroku śmierci. Przypadki powrotu z wygnania uznawano za recydywę karaną stryczkiem ${ }^{20}$. Historiografia anglosaska dokonała gruntownej analizy rozmiaru oraz społecznego i ekonomicznego zna-

${ }^{19}$ W ,piątek, 18 stycznia [1745 r.] Richard Manning i John Davis zostali skazani na stanie pod pręgierzem i na więzienie, pierwszy na 6, a drugi na 3 miesiące za praktyki sodomickie” („Friday, January 18 Richard Manning and John Davis were sentenced to stand the pillory and to be imprisoned, the former for 6 , the latter for 3 months for sodomitical practices”), „London Magazine” 14, 1745, s. 47. Por. R. Trumbach, Sex, Gender, and Sexual Identity in Modern Culture: Male Sodomy and Female Prostitution in Enlightenment London, „Journal of the History of Sexuality” 2, 1991, s. 186-203. Na temat „rytuałów wstydu” por. N.Z. Davis, Society and Culture in Early Modern France, Stanford, Calif. 1975, s. 106-181; W. Beik, The Violence of the French Crowd from Charivari to Revolution, „Past \& Present” 2007, 197, s. 75-110.

${ }^{20}$ Przykładowo: Żyd Jakub Cardoso, skazany na deportację, uciekł (breaking out) z więzienia Newgate, a po schwytaniu został skazany na śmierć. Podobnie R. Parsons, skazany na śmierć za powrót „,przed zasądzonym terminem” zob. „London Magazine” 12,1743, s. 619; „London Magazine” 20, 1751, s. 43. Por. „John Payan otherwise Pidgeon [skazany na śmierć -P.D.] for privately stealing a Watch, who seem'd very much concern'd and begg'd the favour of the Court of Transportation for Life, tho' a reputed pickpocket for about 20 years”, ,London Magazine” 15, 1746, s. 476. 
czenia wyroków deportacyjnych. Przez większość XVIII w. dotyczyły one zsyłki do Ameryki, dokąd w okresie 1718-1775 deportowano ok. 50000 skazańców, przede wszystkim drobnych złodziei, włóczęgów i prostytutek, którzy stawali się „,białymi niewolnikami” i zasilali kolonialny rynek pracy $^{21}$.

Nawet jeśli każdy ze skazanych na śmierć umierał podobnie, procedura i scenografia wieszania różniły się w taki sposób, aby zgromadzona gawiedź posiadała dostateczną wstępną informację o okolicznościach i powodach egzekucji. W poniedziałek 14 marca 1737 r. przed dwoma wózkami, które transportowały skazanych na miejsce kaźni, niesiono wiosło oraz znaki marynarki wojennej: emblematy świadczące, że skazańcy należeli do kategorii określanej mianem „piratów”, a wyroki na nich wydał trybunał morski (Court of Admiralty), instytucja powołana do zajmowania się przestępstwami popełnionymi na morzu oraz na pokładach brytyjskich jednostek. Procedury i zwyczaje sądu admiralicji wymagają dalszego historycznego rozpoznania, wiadomo jednak, że trybunał spotykał się w tym samym budynku co miejski sąd orzekający o sprawach kryminalnych, sesje odbywały się jednak rzadziej, przed sędziami - a potem przed skazanymi - noszono godło tej instytucji - wiosło (tyle że przed sędziami srebrne), a sprawy, które rozstrzygano, dotyczyły w zasadzie „przestępstw popełnionych na otwartym morzu”. Czterech skazańców z marca 1737 r. trudno uznać za piratów - choć publiczna wyobraźnia mogła w nich dostrzegać pobratymców członków osławionego bractwa z Indii Zachodnich. Jak dowodził Marcus Rediker, barwne postaci ,prawdziwych” piratów - karaibskich - znikły w pierwszych dekadach XVIII w. pod naporem zorganizowanej wojskowo-sądowej machiny państwowej ${ }^{22}$. Pozostał jednak ich etos, „romantyczna” wizja morskiej

${ }^{21}$ „London Magazine” 20,1751, s. 43. Na temat deportacji do Ameryki podstawowe znaczenie mają: K. Morgan, The Organization of the Convict Trade to Maryland: Stevenson, Randolph \& Cheston, 1768-1775, „The William \& Mary Quarterly”, 3 seria, 42, 1985, 2, s. 201-227; A. R. Ekirch, Bound for America: A Profile of British Convicts Transported to the Colonies, 1718-1775, „The William \& Mary Quarterly”, 3 seria, 42, 1985, 2, s. 184-200; idem, Bound for America: The Transportation of British Convicts to the Colonies, 1718-1775, Oxford-New York 1987; A. S. Fogelman, From Slaves, Convicts, and Servants to Free Passengers: The Transformation of Immigration in the Era of the American Revolution, „The Journal of American History" 85, 1998, 1, s. 43-76; F. Grubb, The Transatlantic Market for British Convict Labor, ,"The Journal of Economic History” 60, 2000, 1, s. 94-122; idem, The Market Evaluation of Criminality: Evidence from the Auction of British Convict Labor in America, 1767-1775, „The American Economic Review” 91, 2001, 1, s. 295-304; G. Morgan, P. Rushton, Eighteenth-Century Criminal Transportation: The Formation of the Criminal Atlantic, New York 2004; S. Devereaux, Imposing the Royal Pardon, s. 101-138.

${ }^{22}$ M. Rediker, Between the Devil and the Deep Blue Sea: Merchant Seamen, Pirates, and the Anglo-American Maritime World, 1700-1750, Cambridge 1987; idem, Villains of All 
protodemokracji rebeliantów, sprzedawana w postaci jarmarcznych broszur jako literacka konstrukcja rodem z gatunku powieści łotrzykowskiej. Czterej skazani należeli do grona ludzi parających się morskim rzemiosłem, którzy służyli na brytyjskich statkach handlowych, jednak zamiast barwnych „pirackich” występków dopuścili się przestępstw pospolitych i w dodatku na wodach europejskich. Dowiadujemy się, że dwaj z nich mat Williams i marynarz Johnston - zamordowali nożami dowódcę brygantyny Dove, w czasie gdy statek stał na redzie Livorno. Pech chciał, że służący kapitana, świadek mordu, którego także chcieli zabić, wyskoczył za burtę i sprowadził pomoc z innych angielskich jednostek. Inny z „piratów", mat Coyle, okazał się przywódcą buntu wznieconego w sierpniu 1735 r. u wybrzeży Turcji na pince St. John. Ofiarą był kapitan statku, któremu - mimo błagania o litość - rozbito głowę, a trupa wrzucono do morza. Ramię brytyjskiej morskiej sprawiedliwości sięgało jednak daleko i przestępca został w końcu schwytany - w Tunisie - i przewieziony do Londynu. Relacja prasowa, wiernie przytaczając procesowe szczegóły, odnotowała, że skazańców ,powieszono w kajdanach” na znak ich kryminalnej przeszłości i szczególnie „aspołecznej” postawy. W innych przypadkach sądzonych przed Sąd Admiralicji dowiadujemy się, że za „piractwo” uznawano także dezercje, wszelkie przejawy buntu i niesubordynacji, ale także zastrzelenie celnika portowego i włamanie w celu wyniesienia z ładowni statku nieoclonych towarów oraz próbę podpalenia jednostki, aby wyłudzić premię od ubezpieczyciela. „Piratów” nie wieszano razem z innymi kryminalistami w centrum miasta, na Tyburn, procesja ich wózków wędrowała w kierunku Tamizy i kaźń miała miejsce nad rzeką, w miejscu znanym jako „execution dock”23.

Nie sięgając dalej niż znana praca Erica J. Hobsbawma o społecznych korzeniach bandytyzmu, trzeba zwrócić uwagę, że równolegle z wizerunkiem bezbożnego, zadziornego, ale bliskiego „prostym ludziom” pirata funkcjonował wizerunek jego „lądowego" odpowiednika - bandyty grasującego na drogach (highwayman), który okrada podróżnych i nie cofa się przed zagarnięciem prywatnego i publicznego mienia ${ }^{24}$. Bogactwo tego motywu literackiego, znanego w jego nowożytnym wydaniu od tatrzańskiego podgórza (początków XVIII w.) do amerykańskiej prerii (w XIX stuleciu), nie

Nations: Atlantic Pirates in the Golden Age, Boston 2004. Por. interesujące studium piractwa na Oceanie Indyjskim: P. Risso, Cross-Cultural Perceptions of Piracy: Maritime Violence in the Western Indian Ocean and Persian Gulf Region during a Long Eighteenth Century, "Journal of World History" 12, 2001, 2, s. 293-319.

${ }^{23}$ „London Magazine” 6, 1737, s. 163-164; „London Magazine” 12, 1743, s. 619; „London Magazine”, 23, 1754, s. 91; S. Devereaux, Recasting, s. 139.

${ }^{24}$ E.J. Hobsbawm, Bandits, New York 1969. 
wymaga dłuższego przypomnienia, chociaż - jak stwierdzał Lincoln Faller - obfitość tak pisanej kryminalnej biografii była zasługą głównie angielskiego rynku czytelników tej literatury. Gillian Spriggs, autorka monografii angielskiego bandytyzmu, podkreślała swoisty „kult uzbrojonego przestępcy". Istotne są także transformacje tego motywu: Juraj Janosik, słowacki bandyta z trenczyńskiego powiatu powieszony 17 marca $1718 \mathrm{r}$. (za rozboje, ale nie za morderstwo), zyskał drugie życie w ponad sto lat od egzekucji jako romantyczne wcielenie obrońcy Słowaków przed feudalnym uciskiem, podczas gdy jego angielski rówieśnik Dick Turpin - lider bandyckiego gangu i bohater literackich nowelek - nie wahał się użyć broni ze śmiertelnym skutkiem ${ }^{25}$. Ważniejsze jest jednak - by powrócić do chwili, w której przestępcy wymierzona zostaje zasłużona kara - że narracje o śmierci „bandytów drogowych” zdają się często przyjmować odmienny kod opisu niż ten, którym relacjonowano wieszanie innych skazańców. Zamiast skruchy i budujących przemówień Turpin i wielu jego naśladowców - „dżentelmen Jack” Sheppard, powieszony 16 listopada 1724 r., czy lider bandyckiego gangu Jonathan Wild, ukarany w rok później okazywali tłumowi w godzinę śmierci butną i zuchwałą twarz, drwili z wymiaru sprawiedliwości, jadąc na szubienicę, wymieniali uśmiechy z kobietami, noc poprzedzającą kaźń spędzali (w więzieniu) wśród brzęku kielichów i przy kartach, publicznie drwili ze zdawałoby się obowiązującego paradygmatu skruchy ${ }^{26}$. Każda próba opisania „wisielczego” rytmu miejskiej kultury w kategoriach dydaktycznego teatru powinna brać pod uwagę nie tylko zamierzony scenariusz prowadzący od udowodnionej winy i orzeczonej kary do publicznie okazanej skruchy, ale także indywidualne i sterowane innym kodem - oporu lub uległości - reakcje najważniejszych „aktorów” tych dramatów. „Wczoraj rano - podawał do wiadomości swoich czytelników „Universal Magazine” pod datą 14 lutego 1765 r. -

${ }^{25}$ Losy bandy Turpina rekonstruował Derek Barlow, Dick Turpin and the Gregory Gang, London-Chichester 1973. Transformacje legendy Janosika omawia (z wcześniejszą literaturą) Martin Votruba, Hang Him High: The Elevation of Janosik to an Ethnic Icon, "Slavic Review” 65, 2006, 1, s. 24-44. Migracje legend i eksplozje literatury „bandyckiej" omawia Lincoln B. Faller, Criminal Opportunities in the Eighteenth Century: The "Ready-Made” Contexts of the Popular Literature of Crime, ,Comparative Literature Studies" 24, 1987, 2, s. 120-145; idem, Turned to Account: The Forms and Functions of Criminal Biography in Late Seventeenth-and Early Eighteenth-Century England, New York 1987.Zob. M. Harris, Trials and Criminal Biographies: A Case Study in Distribution, w: Sale and Distribution of Books from 1700, red. idem, R. Myers, Oxford 1982, s. 1-36; G. Spriggs, Outlaws and Highwayman: the Cult of the Robber in England from the Middle Ages to the Nineteenth Century, London 2001, s. 12.

${ }^{26}$ 〈http://www.stand-and-deliver.org.uk/highwaymen/famous_highwaymen. htm> (dostęp: 17 V 2012). Por. A. McKenzie, Martyrs, s. 183 nn.; P. Smith, Executing Executions, s. $245 \mathrm{nn}$. 
„w konsekwencji wyroków karę śmierci na Tyburn wykonano wobec Matthew Jamesa - za fałszerstwo, Johna Warda - za rabunek na Moorfields, Johna Routon - za włamanie na Chick Lane, oraz Edwarda Williamsa - za włamanie i kradzież zastawy z domu szlachetnie urodzonego hrabiego Verney. Williams, nie bacząc na licznych widzów, modlił się żarliwie całą drogę od Newgate do miejsca egzekucji, Ward umarł jako papista i odwrócił się plecami do wielebnego [duchownego], a Routon, w okolicy St. Giles' Pound zdjął buty i rzucił je w tłum"27. Williams spełnił przynajmniej minimum pokładanych w nim przez „kulturową poprawność” nadziei. Ward okazał się heretykiem, katolikiem, którego tłum uważał za obcego (zapewne był Irlandczykiem) i za wroga, natomiast trzeci z wymienionych - sądząc z typu wykroczenia jakie popełnił, przestępca pospolity, od jakich roiło się na londyńskich ulicach - wykonał manifestacyjny gest wyzwania wobec zgromadzonych gapiów, znak rozpaczy i bezsilnej wściekłości.

Wróćmy zatem do ostatniej podróży Samuela Ortona. Czy zakryty powóz zamiast odkrytego wózka (dopiero w 1763 r. zaczęto wózki obijać kirem) był znakiem specjalnego wyróżnienia tego skazańca? Czym zasłużył sobie na takie traktowanie, lepsze niż setek innych, których zebrana publiczność mogła oglądać w czasie kilkugodzinnego przejazdu z więzienia Newgate na stołeczną szubienicę? Relacja prasowa wspomina, że „po przybyciu na miejsce egzekucji skazańcy zachowywali się pobożnie i okazywali skruchę. Pan Orton pożegnał się z kilkoma przyjaciółmi z wielkim spokojem, ale Thornhill, zanim wózek spod nich odjechał [co równało się powieszeniu - P.D.], pięć razy podnosił kaptur i zdało się, że bardzo niechętnie żegna się ze światem"28. Już na wstępie zastanawiać może fakt, że Ortonowi towarzyszyli ludzie mu przychylni, przyjaciele. Najczęściej relacje $\mathrm{z}$ wieszania przy Tyburn wymieniały tylko głównych protagonistów, czasem także duchownych, lub (zwykle bezimiennych) urzędników i stróżów prawa, którzy mieli baczenie, aby powagi egzekucji nie zakłóciły niestosowne wybryki tłumu ${ }^{29}$. Londyński plebejski skazaniec nie mie-

27 „Yesterday morning, Matthew James, for forgery, John Ward, for robbery in Moorfields, John Routon, for house-breaking in Chick-lane, and Edward Williams for robbing the house of Right Hon. Earl Verney of plate, etc. were, pursuant to their sentences, executed at Tyburn. Williams, regardless of the numerous spectators, prayed in the most fervent manner from Newgate to the place of execution, Ward dying a Papist, turned his back upon the mnister, and Routon near St. Giles's-pound pulled off his shoes and threw them among the crowd”, ,Universal Magazine” 36, 1765, s. 108.

${ }^{28}$ „When tey come to the place of execution the behaved devoutly and penitently. Mr. Orton took leave of some friends with great Composure, but Thornhill, before the cart drew from under them [--] put up his cap five times seeming very unwilling to leave this world”, ,London Magazine” 36, 1767, s. 41.

${ }^{29}$ Zaskakująco mało wiadomo o londyńskich katach. Byli opłacani z kasy miej- 
wał raczej przyjaciół, o których pisano: częściej mowa jest o kamratach, wspólnikach lub innych członkach bandy, jeśli do niej należał ${ }^{30}$. Orton zachowywał się inaczej niż Thornhill - poważnie i z godnością. Był dużo starszy niżjego trzej towarzysze niedoli. Statystyki skazańców deportowanych do Ameryki wskazują, że przestępstwa popełniali przeważnie młodzi bezrobotni lub niewykwalifikowani mężczyźni (wśród deportowanych prawie $40 \%$ było w wieku do 24 lat) ${ }^{31}$.

Orton był zupełnie kimś innym - przedsiębiorcą i ojcem rodziny. Biorąc pod uwagę jego stonowane zachowanie, należałoby oczekiwać, że pogodzony już z losem - wygłosi z szafotu budującą orację, wpisze swoją śmierć w szerszy i nadal żywy kontekst etycznie zorientowanej propagandy. Wybrał jednak inny sposób komunikowania się z opinią publiczną: zamiast mówić do zebranych u podnóża szafotu, na kilka dni przed egzekucją spowodował - dzięki poparciu duchownego, który udzielał mu w więzieniu duchowej posługi - wydrukowanie w londyńskiej prasie „listu otwartego", w którym szczegółowo wyjaśniał okoliczności będące powodem tego, że znalazł się w więzieniu i oczekiwał egzekucji na Tyburn.

skiej (na początku XVIII w. z roczną pensją 40 funtów), czerpiąc także zysk z łapówek m.in. za skuteczne, tzn. bezbolesne powieszenie, opłat wnoszonych przez rodziny za zabranie ciała na cmentarz lub przez lekarzy - do prosektorium. Wydaje się, że często rekrutowano ich z kryminalistów, wielu wchodziło w kolizję z prawem. Kat John Price (funkcję pełnił od 1714 r.), były marynarz, chronicznie zadłużony pijak (osadzony w tzw. wiezieniu dłużników), zamordował po pijanemu uliczną sprzedawczynię jabłek i został powieszony w 1718 r. Jego następcę Williama Marvela w 1719 r. deportowano za kradzież dziesięciu jedwabnych chustek, a Thomasa Thurlisa (kata w latach 17521771, co oznaczało, że wieszał Ortona) zatrzymano w 1763 r. za kradzież węgla z piwnicy sąsiadów (przed sądem tłumaczył się biedą). Zob. G.D. Robin, The Executioner: His Place in English Society, „The British Journal of Sociology” 15, 1964, 3, s. 237.

30 Por. następującą relację: „Several constables of St. Andrew's Holbourne attended by a large party of the foot-guards went with a search warrant to a noted publik-house on Saffron Hill in order to detect a large gang of street-robbers, pickpokets, loose women etc. and having surrounded it both before and behind, they secured ten men and two women, and carried them before justice Hole who, after a long examination committed them to Clarkenwell Bridewell. This gang was said to consist of about 50, tho' no more happened to be in the house, when officers came. One of them attempted to make his escape from the house-top, but a soldier firing at him, he surrendered”, „London Magazine” 18, 1749, s. 141. Londyn uchodził w XVIII w. za najgorzej chronione miasto w Europie, pozbawione zawodowej (jak w Paryżu) służby policyjnej. Organizacje parapolicyjne, m.in. obywatelskie nocne straże parafialne (w 152 parafiach miasta), funkcjonujące przed reformą 1829 r. omawia Elaine A. Reynolds, Before the Bobbies: The Night Watch and Police Reform in Metropolitan London, 1720-1830, Stanford, Calif. 1998. Por. wzorowe studium zorganizowanej przestępczości: F. Egmond, Crime in Context: Jewish Involvement in Organized Crime in the Dutch Republic, ,Jewish History" 4, 1989, 1, s. 75-100; o użyciu kapturów (aby widzowie nie oglądali twarzy w czasie kilkuminutowej agonii) zob. S. Devereaux, Recasting, s. 157.

${ }^{31}$ A.R. Ekirch, Bound for America: A Profile, s. 195. 
Ukazała się także broszura szczegółowo relacjonująca proces i wyrok. Sam fakt sięgnięcia przez oskarżonego za pióro i skorzystania z możliwości dotarcia do o wiele szerszego audytorium niż to, które oglądało jego egzekucję, wskazuje na odmienność kulturowej i społecznej wrażliwości, do której się odwoływał. Czy był to dowód owej „genezy milczenia”, czyli procesu, jaki wedle Petera Burke zachodził w Europie od połowy XVII w. i oznaczał podporządkowanie ludzkich zachowań - także tych wyrażanych słowami - nowo promowanym wymogom poprawności i dyscypliny w relacjach międzyludzkich $?^{32}$

List otwarty Ortona przywoływał kryteria i kategorie należące do innej przestrzeni ekonomicznej i innych relacji międzyludzkich niż te, które możemy odczytać ze wzmianek o stylu, miejscu i sposobach działania większości skazańców. Orton należał do „innego świata” niż Joseph Leath, który pojechał wisieć za kradzież dokonaną w karetce pocztowej, przecząc zasadzie, iż kiedy ciasno, to łatwo, niż John Gerrard, kieszonkowiec, który pojechał na Tyburn, ponieważ w teatrze przy Drury Lane zgrabnie (choć jednak niedostatecznie sprawnie) wyjął z kieszeni widza haftowaną chusteczkę, albo niż Thomas Hill, który trudnił się sprzedawaniem podrobionych kart do gry. Orton nie należał do ulicznych łazików, którzy kradli przedmioty łatwo wpadające w ręce złodziei i włamywaczy - zegarki, sakiewki, zastawę stołową, pościel, ubrania - i które współczesnych badaczy zasobów „kultury materialnej" osiemnastowiecznego Londynu przekonują o trwałym procesie bogacenia się nawet nisko uplasowanych grup miejskiego społeczeństwa $^{33}$. Anonimowy duchowny, który troszczył się o Ortona w więzieniu, pozostawił - także opublikowany w gazecie - nader pochlebny wizerunek skazanego. Dowiadujemy się, że był on synem serowarów z parafii św. Marcina ,in the Fields”, odebrał dobrą szkolną edukację na prowincji, terminował u londyńskiego księgarza, dzięki „wpływowym krewnym” otrzymał w 1749 r. posadę pisarza na pokładzie okrętu wojennego. Okazywał się człowiekiem pełnym zalet, urzędnikiem sumiennym, szczerym i honorowym. Kiedy zszedł na ląd - pisał duchowny, dostrzegając w dalszych decyzjach Ortona zalążki zagrożenia dla kariery młodego człowieka - „postanowił zrobić fortunę na handlu winem i brandy i przez to położył kamień węgielny pod swój upadek"34. Na pierwszy rzut oka już widać, że poruszamy się w kręgu odmiennym od społecznej afiliacji większości skazańców przywożonych na Tyburn. Orton należał do wyraźnie już w XVIII w. widocznej an-

${ }^{32}$ A True and Genuine Account of Samuel Orton, who was Executed at Tyburn, on Wednesday January 14, 1767 for a Forgery upon the Bank, wyd. E. Hood, [London] 1767. Por. P. Burke, The Art Of Conversation, Cambridge 1993, s. 140.

33 „London Magazine” 12, 1743, s. 619.

34 „London Magazine” 36, 1767, s. 36-37. 
gielskiej „,klasy średniej” - pojęcia używam świadomy zainicjowanej przez Edwarda P. Thompsona wieloletniej debaty nad społeczną kategoryzacją „przedprzemysłowej” Angliii ${ }^{35}$ - i choć zajmował w niej miejsce, które najłatwiej opisać socjologicznie trafnym przymiotnikiem ,lower”, to z racji intelektualnych i profesjonalnych atrybutów zakorzenienia w tej warstwie społecznej jego przynależność do osiemnastowiecznej przestrzeni awansu i sukcesu nie może budzić większych wątpliwości. List otwarty Ortona, napisany w więzieniu na tydzień przed egzekucją, miał na celu oczyszczenie jego nazwiska - już to separowało go od innych skazańców, którzy nie mieli ani odpowiednich „kontaktów”, ani środków, ani zapewne pomysłu i potrzeby, aby podjąć taką inicjatywę. Obrona dobrego imienia znamionuje odmienną od świata londyńskich rzezimieszków postawę tego skazańca, różni go także od bandytów z gościńca, „,bohaterów” ludowych narracji, którzy w obliczu śmierci zachowywali się bardzo ekstrawagancko i buńczucznie i zdawali się do końca rzucać wyzwanie systemowi sprawiedliwości. Orton nie umierał ani jak zuchwały highwayman, ani jak skruszony przestępca, przekonany do zapewnienia zebranej gawiedzi moralizującej powiastki zakończonej pokazem wisielczej agonii. Szubienica nie była dla niego jedynym i ostatecznym punktem odniesienia $\mathrm{w}$ jego życiowych i zawodowych uwikłaniach. List - zbyt długi i szczegółowy, by analizować każdy jego fragment - nie jest ani zapisem buntu przeciwko wyrokowi, ani błaganiem o wybaczenie i nie zawiera także jasnego przesłania nawiązującego do motywu wyznań skruszonego przestępcy, tak silnie zakorzenionego w „penitencjarnej” tradycji przekazów kierowanych z miejsca publicznych egzekucji ${ }^{36}$. Zamiast odzianym w moralne exempla biadaniem nad ponurym losem, jest wykładem praktyki prowadzenia biznesu w osiemnastowiecznym Londynie, zamiast błaganiem o wybaczenie grzesznego żywota - ledwie skrywanym oskarżeniem mechanizmów finansowych, które spowodowały, że hurtownik alkoholi znalazł się w pułapce długów i zdecydował się - choć jego interpretacja tej sytuacji musiała być inna niż ta, którą przyjął sąd - na sfałszowanie weksla. Pomijając inne elementy wywodu, jeden zwraca osobną uwagę. Orton mówił o sumach - setkach funtów -

${ }^{35}$ Zob. E. P. Thompson, Patrician Society, Plebeian Culture, ,Journal of Social History” 7, 1973-1974, s. 382-405; idem, Eighteenth-Century English Society: Class Struggle without Class?, ,Social History” 3, 1978, s. 133-165 oraz zbiór zebranych studiów idem, Customs in Common, London 1991. Socjologia historyczna Thompsona wpłynęła bezpośrednio na sposób analizy prawa karnego proponowany przez „szkołę z Warwick”. Krytykę przeprowadził P. King, Edward Thompson's Contribution to Eighteenth-Century Studies: The Patrician-Plebeian Model Re-Examined, „Social History” 21, 1996, s. 215-228.

${ }^{36}$ List opublikowały „London Magazine” 36, 1767, s. 37-38 i „Gentleman’s Magazine" 39, 1767, s. 20. 
dla innych skazańców, z jakimi dzielił los, nieosiągalnych, istniejących w przestrzeni ekonomicznej, do której nie mieli dostępu, zadowalając się jak bokser James Field, którego łupem, poza okularami ofiary, padło 13 szylingów, czy trójka bandytów dzieląca się trzema funtami, siłą zabranymi przechodniowi koło Covent Garden - kwotami dla nich atrakcyjnymi, znaczącymi tylko w przestrzeni zajmowanej przez ,proletariuszy”, natomiast w tej, którą wyznaczały interesy prowadzone przez Ortona, pozbawionymi ekonomicznego znaczenia ${ }^{37}$.Znaczenie miało jednak to, że znalazł się w kłopotach, polegających na tym, iż w jego rękach znalazły się wymagające szybkiego spłacenia weksle osób uznanych za bankrutów, a główny wierzyciel - i jak należy wnosić biznesowy partner - kapitan Thomas Bishop właśnie powrócił z rejsu i oczekiwał rozliczeń. Orton upierał się, że podjął kroki, aby nie znaleźć się wśród niewypłacalnych, dobrze wiedział, że oznaczało to nie tylko poważne tarapaty - listy bankrutów codziennie publikowała londyńska prasa - ale też relegowanie z grupy odpowiedzialnych biznesmenó $w^{38}$. „Proszę zwrócić uwagę - pisał z więzienia - że gdybym miał najmniejszy zamiar oszukać bank, albo kapitana, to wyjechałbym za granicę na wieść o jego powrocie do Portsmouth [--]. Miałem częste możliwości opuszczenia mojego kraju, ale myśl o okropnych tego konsekwencjach nie powstała mi w głowie” („London Magazine” 36, 1767, s. 37-38).Znalazł się w trudnej sytuacji - nie miał jak spłacić wierzyciela, obawiał się ruiny finansowej, ponieważ był zadłużony na poważną jak na drobnego przedsiębiorcę kwotę ponad 2000 funtów. W desperacji - o czym jednak pisze raczej oględnie - sfałszował pełnomocnictwo Bishopa, który powierzył mu obracanie swoimi akcjami i inwestowanie nadwyżek pieniędzy,jakie przynosiła służba na morzu. Przywłaszczenie sobie pakietu akcji Banku Anglii, wartego 500 funtów (inne źródła mówią o kwocie dwa razy wyższej), mogło - przypuszczalnie - zażegnać widmo bankructwa, ale nieoczekiwany powrót kapitana przyspieszył bieg wydarzeń. Czy fałszerzowi można uwierzyć, kiedy informował czytelników, że natychmiast podjął kilka prób przeprowadzenia rozmowy z partnerem, zapewne w celu wyjaśnienia mu sytuacji i spłacenia - w co głęboko wierzył - jego znacznych roszczeń? Jak opowiadał londyńskim czytelnikom - oczekując na kolejne spotkanie, został aresztowany.

37 „London Magazine” 20, 1751, s. 43, 235. Środowisko londyńskich żebraków analizował T. Hitchcock, Begging on the Streets of Eighteenth-Century London, ,Journal of British Studies" 44, 2005, 3, s. 478-498. Por. P. Spierenburg, Close to the Edge: Criminals and Marginals in Dutch Cities, „Eighteenth-Century Studies” 31, 1998, 3, s. 355-359.

${ }^{38} \mathrm{Na}$ złożoną procedurę i trudności w oszacowaniu liczby osób uznanych za bankrutów zwracała uwagę Sheila Marriner, English Bankruptcy Records and Statistics before 1850, „The Economic History Review”, nowa seria, 33, 1980, 3, s. 351-366. 
Osnową opowieści Ortona nie jest problem winy ani pokuty, choć wyrok śmierci zdawał się przyjmować już z pewną rezygnacją, która mogła znamionować wpływ rozmów z duchownym i pogodzenie się z Bogiem ${ }^{39}$. Chodzi przede wszystkim o zawiedzione zaufanie. Kilkakrotnie podkreślał, że ze swoim głównym wierzycielem, kapitanem Bishopem, rozstawał się ,jak przyjaciel”, natomiast fakt, że to właśnie Bishop spowodował doniesienie, które skutkowało jego aresztowaniem, był dla Ortona gorzkim zaskoczeniem. Jak wskazywała Laurence Fontaine, wczesnonowożytne relacje finansowe, polegające przede wszystkim na trwałości kredytu i wszechobecnym obrocie wekslami, były zbudowane na wzajemnym zaufaniu ludzi biznesu i choć francuskie „à credit” oznaczało pierwotnie - jeszcze w końcu XVII w. - działanie emocjonalne i bezcelowe, to ewolucja tego pojęcia i jego transformacja w angielskie „credibility” pokazuje kierunek nie tylko semantycznej wędrówki, ale także stojącego za nią procesu nadawania pozytywnej wartości relacjom, w których nawet nieznający się osobiście ludzie gotowi byli honorować swój podpis i na jego podstawie gwarantować pieniądze. Z drugiej strony, eksplozja gospodarki rynkowej i możliwości kredytowych „kupieckiego kapitalizmu”, dobrze już widoczna na początku XVIII w., ułatwiała nadużywanie zaufania, skłaniała do spekulowania łatwo dostępnymi środkami - obligacjami, akcjami, prywatnymi wekslami - tworzyła miraż bogactwa i generowała dotąd nieznane pokusy $^{40}$. Jeśli P. Spierenburg opowiadał amsterdamskie historie „fatalnego zauroczenia" okraszone mrocznymi aspektami osiemnastowiecznej miłości, to przypadek Ortona dostarcza dowodu na działanie innej emocji, na skuteczność pułapki naiwności, w jaką mógł popaść raczkujący biznesmen - syn serowarów i pokładowy pisarczyk - którego przerosły rynkowe wymagania i finansowe zobowiązania. Dla zrozumienia społecznych i kulturowych ram potrzasku, w którym znalazł się Orton, podstawowe znaczenie mają ustalenia Randalla McGowena wskazał on, że postrzeganie kategorii fałszerstwa, pierwotnie karanego grzywną i „zawstydzającym” wyrokiem pręgierza, uległo po przyjęciu

${ }^{39} \mathrm{Na}$ trwałość odczytywania w kategoriach religijnych zasądzonej przez sąd kary wskazywał J. A. Sharpe, Civility, Civilizing Process, and the End of Public Punishment in England, w: Civil Histories. Essays Presented to Sir Keith Thomas, red. P. Burke, B. Harrison, P. Slack, Oxford 2000, s. 121 n.

${ }^{40}$ L. Fontaine, Antonio and Shylock: Credit and Trust in France, c. 1680-c. 1780, „The Economic History Review”, nowa seria, 54, 2001, 1, s. 39-57. Historię „baniek spekulacyjnych" omawiają prace: P. M. Garber, Famous First Bubbles: The Fundamentals of Early Manias, Cambridge, Mass. 2000; E. Chancellor, Devil Take the Hindmost: A History of Financial Speculation, New York 1999. 
nowej ustawy w 1729 r. znacznemu zaostrzeniu. Podrobienie podpisu i wyłudzenie pieniędzy przestało być wykroczeniem „prywatnym”, ponieważ prawnicy i urzędnicy królewskiego aparatu sprawiedliwości uznali, że narusza stabilność państwa, jest zagrożeniem porządku publicznego, który funkcjonuje sprawnie dzięki wykluczeniu oszustów finansowych z grona ludzi obracających pieniędzmi ${ }^{41}$.

Czy przypadek Samuela Ortona znacząco zmieniał reguły londyńskiego „teatru śmierci”? Sam czyn, za jaki został skazany, nie był ewenementem, nieznanym sądom. Po 1729 r. fałszerstwo zaliczano do ciężkich przestępstw przeciwko mieniu i wyroki - najczęściej skazujące na śmierć pojawiają się w orzeczeniach trybunałów z rosnącą częstotliwością, świadcząc z jednej strony o dynamice rozwoju rynku publicznych i prywatnych finansów, a $z$ drugiej o podatności na nadużycia systemu niedysponującego gotówką i uzależnionego od obrotu jej surogatami. Bezwzględność, z jaką sądy traktowały fałszerzy, odzwierciedlała przekonanie państwowego aparatu sprawiedliwości i instytucji finansowych, że podrabianie podpisów stanowiło żywotne zagrożenie dla modus operandi całego systemu gospodarczego. Obwieszczenia o wyrokach na fałszerzy pojawiały się w gazetach regularnie. W czasie grudniowej sesji londyńskiego trybunału w 1743 r. na 13 wyroków śmierci jeden dotyczył sfałszowania weksla, w styczniowej sesji w 1751 r. wydano trzynaście wyroków śmierci, wśród których dwa dotyczyły fałszerstwa, w kolejnej sesji zasądzono 9 wyroków śmierci, w tym jeden za fałszerstwo ${ }^{42}$. Powieszenie Ortona nie było zatem niczym nowym, w mediach potraktowano go jednak ze znacznie większą uwagą niż innych fałszerzy. Sprawy dotyczące finansowych machinacji oraz rzeczywistych lub domniemanych „przekrętów” rozgrywały się najczęściej w środowiskach londyńskiej „middle class”. W liście pisanym z więzienia Orton opowiadał o swoich biznesowych podróżach do angielskich portów - handlował alkoholem, ale nie był szynkarzem, który by obsługiwał bandycką i „proletariacką" subkulturę ulicy, świadomie kreślił swój wizerunek przedsiębiorcy. Opis stylu życia i pracy, jaki proponował czytelnikom, definiował - na pewno w jego mniemaniu - jego „klasową" i miejską obecność. Z podobnym zderzeniem wizerunku rzetelnego biznesmena $\mathrm{z}$ katastrofą spowodowaną próbą oszukania zasad własnego etosu - jak pokazują procesy bliźniaków Perreau czy wielebnego Dodd'a spotykamy się w XVIII w. dość często. Sprawy te wywoływały zaskoczenie,

${ }^{41}$ P. Spierenburg, Written in Blood, s. 13 nn.; R. McGowen, From Pillory to Gallows: the Punishment of Forgery in the Age of the Financial Revolution, „Past \& Present” 1999, 165, s. $107-140$.

42 „London Magazine” 12, 1743, s. 619; „London Magazine” 20, 1751, s. 43, 235. 
rodziły znaczne wątpliwości merytoryczne i proceduralne, które nie wpłynęły jednak na zmianę surowych orzeczeń i dopiero po 1830 r. przyczyniły się do zmiany karnej kwalifikacji samego czynu ${ }^{43}$. Samuel Orton starał się zaznaczyć odmienność swojej sprawy - i społecznej kondycji oraz podkreślić własne środowiskowe i jednostkowe ,ja”: w korespondencji z więzienia, z lochu skazańców, tak zimnego, ,że nie mógł się nawet pomodlić", domagał się - na kilka dni przed śmiercią - przeniesienia do innej celi, prosił czytelników o wybaczenie mu błędów w pisaniu i z wielką determinacją zabiegał u miejskich urzędników o zgodę na odbycie ostatniej podróży zakrytym powozem ${ }^{44}$. Były to zabiegi, dzięki którym podtrzymywał do końca wizerunkowy aspekt swojej tożsamości, bronił dobrego imienia i chciał uniknąć naznaczenia infamią. Miał świadomość, że zostawia żonę i dzieci, krąg przyjaciół i handlowych partnerów. Swoim zachowaniem wpisywał się w środowisko, dla którego normą zachowania stawała się płynnie jeszcze definiowana „grzeczność”, wielkomiejska ogłada, poprawność i obycie w życiu codziennym oraz „przyzwoitość” w działalności zawodowej ${ }^{45}$. Jak dowodził Miles Ogborn, konstruowanie tkanki życia publicznego w XVIII w. coraz bardziej zaczęło polegać na świadomej obecności „prywatnych jednostek”, odmiennych - i odseparowanych od amorficznego, agresywnego ulicznego tłumu ${ }^{46}$. Można więc spekulować, że skazany chciał umrzeć „po swojemu”: lochy w Newgate miały złą sławę i zdarzało się, że więźniowie umierali, zanim wykonano na nich wyrok (co nie zwalniało od obowiązku powieszenia ich ciała), na Tyburn oczekiwał go karawan ${ }^{47}$, aby zabrać ciało na cmentarz i uniknąć sytuacji

${ }^{43}$ C. Muldrew, The Economy of Obligation: The Culture of Credit and Social Relations in Early Modern England, London 1998; D. T. Andrew, R. McGowen, The Perreaus and Mrs. Rudd: Forgery and Betrayal in Eighteenth-Century London, Berkeley 2001.

44 „London Magazine” 36, 1767, s. 38.

${ }^{45}$ Dyskusja ta ma kluczowe znaczenie dla opisu angielskiej tożsamości XVIII w. Użyteczny wstęp proponują: H. French, The Search for the "Middle Sort of People” in England, 1600-1800, „The Historical Journal” 43, 2000, 1, s. 277-293; P. Langford, The Uses of Eighteenth-Century Politeness, „Transactions of the Royal Historical Society” 6 seria, 12, 2002, s. 311-331; L. E. Klein, Politeness and the Interpretation of the British Eighteenth Century, „The Historical Journal” 45, 2002, 4, s. 869-898; K. Harvey, The History of Masculinity, circa 1650-1800, ,Journal of British Studies” 44, 2005, 2, s. 296-311.

${ }^{46}$ M. Ogborn, Spaces of Modernity: London's Geographies, 1680-1780, New York-London 1998, s. 79 n. Por. R. B. Shoemaker, op. cit., s. 97-131.

${ }^{47}$ Więzienie wykorzystywało konstrukcje średniowiecznej zachodniej bramy wjazdowej do Londynu. Uchodziło za wyjątkowo niezdrowe. Epidemia tyfusu rozprzestrzeniła się w 1750 r. na przylegające budynki sądu, powodując śmierć kilku sędziów i ławników. Przebudowę (trzy bloki: dla dłużników, kobiet i mężczyzn) rozpoczęto w 1770 r., ale nowe pomieszczenia spłonęły w 1780 r. w czasie rozruchów. Zob. H. D. Kalman, Newgate Prison, „Architectural History” 12,1969, s. 50-61. Na temat ewolucji zawodu przedsiębiorcy pogrzebowego (od cechowej reglamentacji do rynkowej konkurencji) zob. 
jednego z towarzyszy ostatniej podróży, Walkera, skazanego za napad na gościńcu, którego koledzy (marynarze) porwali spod szubienicy, aby trup nie wpadł w ręce lekarzy w celu wykonania sekcji i prowadzenia badań anatomicznych, co w opinii londyńskiej ulicy uznawano za ostateczną i hańbiącą degradację. Zabiegi te nie przeszły publicznie niezauważone.Jak pisano, „pan Orton był pierwszym przestępcą - poza lordem Ferrers - który na Tyburn udał się powozem" ${ }^{48}$. Porównania z arystokratą skazanym i powieszonym kilka lat przedtem za popełnienie morderstwa (ostatnim powieszonym członkiem Izby Lordów; egzekucja miała miejsce 5 maja 1760 r.) nie należy traktować jako szczególnego wyróżnienia dla prawnej kwalifikacji czynu - ta była już w 1767 r.jednoznaczna - raczej można w nim widzieć odkształcenie kwalifikacji społecznej oraz właściwości osobistego, ale mocno środowiskowo osadzonego stylu, który drobny hurtownik alkoholu zdołał wynegocjować z zarządcami londyńskiego ,teatru śmierci”"

\section{By Coach to the Scaffold: Theatres of Remorse in Eighteenth-Century London}

On January 14, 1767 Samuel Orton, London entrepreneur was driven to be hanged by a mourning coach. Most convicts, including those who travelled with him to the traditional city gallows at Tyburn were carted and the magistrates,

P.S. Fritz, The Undertaking Trade in England: Its Origins and Early Development, 1660-1830, „Eighteenth-Century Studies” 28, 1994-1995, 2, s. 241-253.

48 „Mr. Orton was the first criminal (except Lord Ferrers) that has gone to Tyburn in a coach”, „London Magazine” 36, 1767, s. 41.

${ }^{49}$ Przypadek powieszenia trupa (zakutego w łańcuchy) zob. „London Magazine” 6, 1737, s. 163. Skazańcem był Murzyn Jeffrey Morat, winny włamania oraz napadu z intencją popełnienia morderstwa. Do sposobu traktowania ciała po egzekucji przywiązywano dużą wagę i tłumaczono m.in., że „the four Jews that were executed, were interr'd in their Burial-Ground at Mile-End, with their Cloaths on, and the Halters about their Necks, the Jews never stripping and Person, who does not die a natural Death”, „London Magazine” 13, 1744, s. 100. Lord Ferrers zabił służącego, po egzekucji jego ciało zostało oddane lekarzom, zob. J.H. Langbein, op. cit., s. 114. W 1541 r. cech chirurgów otrzymał prawo dokonania sekcji na czterech skazańcach rocznie. Ustawa z 1752 r., tzw. Murder Act, umacniała to prawo, które uznawano za dodatkowe narzędzie wzbudzające strach i powodujące infamię. Zob. P. Linebaugh, The Tyburn Riot Against the Surgeons, w: Albion's Fatal Tree, s. 65-117. W XIX w. rozwinęło się przestępcze „podziemie” oferujące trupy lekarzom. Por. I. Ross, C. Urquhart Ross, Body Snatching in Nineteenth Century Britain: From Exhumation to Murder, „British Journal of Law and Society" 6,1979, 1, s. 108-118. Wydaje się jednak, że te praktyki miały już osiemnastowieczny rodowód. Por.: „On Saturday last a man was committed to New Prison, Clarkenwell charged with stealing diverse bodies from the burrying ground in Whitecross-Street, belonging to the parish of Cripplegate, and selling them to surgeons for two guineas each, on searching the ground empty coffins were found”, „Universal Magazine" 36, 1765, s. 275. 
who granted him this privilege were clearly making an exception. Orton's case and its analysis is informed by the detailed press reports read against the growing research into the evolution of London's XVIII ${ }^{\text {th }}$ century bloody code and urban "theatres of death". Strategies of penalizing crime are seen not as much in the light of statistics of death sentences as through their perception drawn by literate urban audiences from detailed press reports. The scenarios of hanging pirates, highwaymen and petty criminals traditionally included the edifying reports of the "last dying speeches", while Orton, an educated businessman sentenced to death for a "new crime" of forgery (punishable by death only from 1729) chose not to speak at the gallows but instead published an open letter professing himself a victim of market economy based on credit he could not satisfy. A death sentence mitigated by a gesture of granting him a coach is thus - on the one hand - a mark of lawmakers' growing determination to penalize financial transgression, while - on the other - a sign of lingering social and ethical ambiguity about harshness such decisions of the court.

Paweł Dobrowolski 